\title{
Experience Oneness with Creation: The Pathway to Universal Consciousness
}

Joseph Cornell (Nayaswami Bharat)

Sharing Nature Worldwide, Nevada City, California, USA.

\section{Introduction}

$\mathrm{H}$

armony with all living things, said Kirpal Singh, comes from the "recognition that all things are [made of] the same Essence" (Singh, 2016). From my earliest years, I have often sensed a loving presence that permeates this world and has inspired my lifelong service to others.

One day while hiking through a remote valley in Desolation Wilderness, I felt an overwhelming sense of joy-a joy so pervasive that it seemed to animate the flowers, the stones, and the cascading stream. Every blade of grass, every tiny waterfall, and each mossy rock seemed to radiate and rejoice in this all-encompassing joy.

I sat beside a small, snow-fed tarn, encircled by huge granite blocks cleaved by a glacier, delighting in the joy around me. Soon, a robust, cheery little bird (an American dipper) came within a few yards of me and began singing. Its clear, melodious voice echoed superbly against the surrounding rock walls. The bird's vibrant song and its resounding echo greatly amplified the joy I felt that day on the mountain (Cornell, 2013).

Nature's most precious gift, I believe, is the experience of her deeper nature: her stillness, wholeness, and joyful vitality. It was only after beginning a lifetime practice of yoga that I discovered that the source of Nature's joy was AUM $(\mathrm{Om})$, the Cosmic Sound. Gaelic tradition, too, says that creation is The Great Song sung into existence by the Divine Spirit-a song that never ceases.

The Sacred Sound has many names, and mystics of all religions revere it. Spirit, through vibration, creates the universe. In the beginning, says the Bible, God's voice thundered marvelously and moved the waters. His thought vibrations create and animate the heavens and earth. God's love, through Cosmic Vibration, has manifested all creation.
AUM, the Holy Spirit, is called the Comforter, because it gives supreme comfort to the soul.

The Qur'an refers to this sound in the words, "Be! And all became." Moses heard this very sound on Mount Sinai when communing with God; and AUM was audible to Christ when absorbed in his heavenly Father in the wilderness. Shiva heard [AUM] during his Samadhi in... the Himalayas. This sound is the source of all revelation to the masters.... It is because of this that they know and teach one and the same truth. (Khan, 2005)

When one hears the Cosmic Sound, one knows that one could listen to it through all eternity, because AUM is the vibration of one's own being. After hearing AUM, Saint Francis of Assisi described it as music so sweet and so beautiful that, had it lasted a moment longer, he would have melted away from the sheer joy of it.

AUM is the bridge that unites Spirit and Nature, human consciousness with universal consciousness. When one communes with AUM, one knows for a certainty that the Divine Spirit is lovingly present in this world.

God is AUM, and God BECAME creation through AUM. Every atom, every living creature is made of the Cosmic Vibration. While in the wilderness, John Muir felt every cell and atom vibrate with music and life, and the mountains, seemingly, dissolve into the “incomparable Spirit of holy Light” (Hanna, 1954, p. 82). Light, along with sound, is an aspect of AUM.

A human mother sings a lullaby to comfort her baby; the Mother of the Universe sings a lullaby of love to comfort Her creation. Through AUM, Her grace flows into the world. Even wild animals are attracted to the Cosmic Sound. Snakes, deer, and other wild beasts in the forests of the Himalayas have often come to sit beside a hermit who is chanting AUM. AUM's effect on animals shouldn't be surprising, because everything in creation is, in a very real sense, music or vibration; all of nature has been created by the sound of AUM, the purest of all melodies, and it naturally captivates every being. 


\section{THE PATHWAY TO UNIVERSAL CONSCIOUSNESS}

The negative and positive forces in each atom resist each other and produce a quiver. The combined quivers from every vibrating atom in the universe produce the sound of AUM. AUM, devoid of duality, is the only sound not made by striking another object and so is called the "unstruck" sound. AUM's thrilling sounds cannot be heard by physical ears but only by the intuitive power of the soul. Below, a young man describes AUM's pristine quality after hearing it emanate from his heart center:

I heard the sound of church bells and it was utterly beautiful and crystal clear. It had a sense of lightness and clarity unlike anything I have ever experienced. If you can imagine the heaviness of ordinary sound produced by the air it must pass through, this was completely unlike that. It was the essence of sound before it meets air-as if the sound was conveyed on light through space with no grossness whatsoever. (personal correspondence with the author)

AUM solidifies into matter through vibrating at different rates. These different rates become elemental building blocks of ether, air, fire, water, and earth. In nature we can see solidified expressions of these elements: in the emptiness of space, moving air currents, fiery volcanoes, rippling lakes, and majestic mountains.

Just as striking a gong sends ringing through surrounding space, Divine Spirit continuously emanates vibratory AUM to manifest and sustain the universe. When we deeply hear AUM, our consciousness expands with the Cosmic Sound.

\section{Expanding One's Sense of Self}

John Muir said that when one is immersed in nature, the "body vanishes and the freed soul goes abroad" (Hanna, 1954, p. 93). When the life force withdraws into the spine and brain, one experiences another world-a world of Spirit.

One night in Mexico, a friend of mine was standing on a hotel balcony enjoying the city lights spread out before him. Suddenly a power failure plunged the city into darkness. As the lights of the city were darkened, the brilliance of the stars came alive. The glow of the city had overpowered the stars' subtler light. In the same way, focusing on material realities makes one deaf to AUM's mighty roar.

As you hear the inner sounds, you begin to concentrate more and more deeply within. By concentrating on these sounds you'll gradually trace them back to their source in AUM. As you listen more deeply, you'll find your body dissolving within the great sound of AUM; then, expanding beyond the body, you'll find this AUM sound gradually engulfing the world around you. You'll know you are that sound, and it will expand out beyond infinity. And you'll find yourself at one with all creation.
Just as one million cubic feet of air can be compressed into one cubic foot, so is Universal Consciousness compressed by egoic consciousness. When the soul identifies with the body, it confines its awareness of Universal Consciousness to a tiny portion of matter. When compressed air escapes its container, however, it rapidly spreads to fill the surrounding space.

According to yoga science, cosmic energy enters the body through the medulla oblongata, located at the base of the brain. Thence the energy moves down the spine and out through the chakras to different regions of the body. The energy flowing from the heart chakra, for example, radiates outward through the nerve channels to the physical heart, lungs, and chest, and into the arms and hands.

Most people's life energy is locked up in their bodies. Spiritual progress begins when one redirects one's energy inward-changing the center of consciousness from the body and senses to the spine and brain and thus moving from conscious awareness into superconsciousness. Withdrawing the life force is the inner, universal path of all spiritual effort and experience.

Once the mind is interiorized, and withdrawn from its identification with the world and with the body, the inner sounds become all absorbing, according to Paramhansa Yogananda. AUM's inner sounds are often likened to heavenly music because they carry the one who hears them to higher realms. The calmer you become, the more you'll hear and feel the vastness of vibratory creation within you.

The Cosmic Vibration is inaudible to the human ear, but can be heard inwardly by the "ear" of intuition. People sometimes get a hint of it in places where there is complete silence. They may hear a soft hum, or a gentle murmur like the whisper of wind in the trees. The sound emerges from no discernible point in space, but seems rather to come from everywhere. What is heard in quiet surroundings is not so much a spiritually uplifting experience as simply a whisper-like that of a waterfall from afar-of the mighty thunder of AUM perceived in deep meditation. (Swami Kriyananda, 2001, p. 31)

\section{Nature Is My Body}

Communing with AUM makes one fearless and self-assured. One's reality shifts from the ego, which can never be secure, to the Cosmic Vibration, which is the essence of all creation. Ego consciousness isolates us from the rest of life. Those who deeply merge with AUM, however, know and say, "I am the whole universe. What can possibly harm me?"

The Cosmic Vibration is beyond duality; therefore, in its reality, there's no opposite or opposition. In its consciousness, there is no myself against another-but myself as all others. 


\section{CORNELL}

In his book Rays of the One Light, Swami Kriyananda writes, "Human vision beholds individuality and separation everywhere. Divine vision beholds the oneness of cosmic vibration, of which all things, no matter how diverse, are manifestations" (1996, p. 9). Swami Rama Tirtha said, "nature is my body," because through AUM he was literally united with the trees and farthest stars (Singh, 2016, p. 29).

To experience oneness with creation means to merge with that which animates all existence. Sir Francis Younghusband, English explorer and leader of an expedition to Lhasa, had numerous mystical experiences in the silent Tibetan wilderness. One evening, he left camp and went alone into the mountains:

I was free to let my soul relax. So I let it open itself out without restraint.... in its sensitive state it was receptive of the finest impressions.... I felt I was seeing deep into the true heart of things....

My experience was this-I had a curious sense of being literally in love with the world. I felt as if I could hardly contain myself for the love which was bursting within me. It seemed to me as if the world itself were nothing but love.... I seemed in tune with all the world, and all the world seemed in tune with me. (Younghusband, 1921, pp. 167-168)

In stillness, we feel universal love for all things. The greater the calmness, the greater our rapport with nature, because everything responds to the harmony of love.

The Buddhist monk, Godo Nakanishi, once spent several days sitting quietly on a snow-covered mountain. The birds living there noticed him, but fear of humans kept them a safe distance away. As the monk continued to meditate, he became more and more absorbed in the inner silence. Gradually, because of the wonderful peace Godo emanated, the wild birds lost their fear and accepted his presence. A few birds, apparently attracted to the serene monk, landed on his motionless body (Cornell, 2014).

The birds landed on the Buddhist monk not because they found his body a convenient place to perch but because they were attracted to his aura of peace. Interestingly, Godo Nakanishi founded the Wild Bird Society of Japan for the protection of native birds. Today this prominent organization has 51,000 devoted members.

It is the nature of bliss to share its joy with others. In a letter, Muir declared, "I care to live only to entice people to look at nature's loveliness. My own special self is nothing. [I want to be] like a flake of glass through which light passes (Wolfe, 1945, pp. 175, 154).

After long, snowy winters, deciduous trees have the power to restore themselves. In early spring, the vitality of life flows ener- getically (and almost magically) through the forest. Similarly, you can experience Life's universal enlivening force through attuning to Cosmic AUM. Harmonizing with this force, you will feel an exhilarating love for all creation.

\section{Exercises for Seeing AUM in Nature}

During the Seeing AUM in Nature exercises, feel the presence of AUM in everything you see and hear.

\section{The sun is the form of AUM}

Look at the sun. See its rays flowing down, warming the nearby hills and enlivening the trees and flower-covered meadows. Reflect on how all life depends on the sun. Gaze at a plant and feel how it is nourished by the great power emanating from our star.

Just as an iceberg is formed of water, so the sun is formed of AUM. "The sun," Kabir said, "is the most immediate "physical' form of AUM we can experience, for it is really solidified, materialized AUM.”

Think of the sun as AUM materialized.

Feel its vibratory rays descending from heaven and bringing into manifestation and sustaining life around you.

See each bird and flower as AUM solidified. Behind every form, sense AUM's underlying presence and vibrancy. Feel and hear all nature proclaiming and singing AUM.

\section{Let every sound remind you of AUM}

Listen intently to the sounds around you: the rushing wind-the roar of a river-the buzzing of a bee-the joyful song of a bird. Commune with each sound you hear. Open yourself completely to it; feel it coming into you. Listen for and feel AUM in every outer sound.

Watch the wind flow through the trees and grassy fields. See in every trembling leaf and sailing cloud-in every movement-Sacred AUM vibrating.

Try to perceive AUM in everything you do, see, and hear.

Observe the ways Spirit, through Cosmic AUM, expresses Itself. See how the Invisible Mother, in creation, has become visible.

Notice how each tree, like each person, is marvelously unique. Take delight in the countless expressions of AUM you see before you.

Communing with AUM helps one understand and utter the language of all creation. When one unites with AUM, one unites with all existence.

\section{Author Note}

"Experience Oneness with Creation" originally appeared on the Ananda.org blog on February 5, 2020. 


\section{THE PATHWAY TO UNIVERSAL CONSCIOUSNESS}

\section{Author Disclosure Statement}

No competing financial interests exist.

\section{Funding Information}

No funding was received for this article.
Swami Kriyananda (Walters, J. D.). (2001). The promise of immortality: The true teaching of the Bible and the Bhagavad Gita. Nevada City, CA: Hansa Trust, Crystal Clarity Publishers.

Wolfe, L. M. (1945). Son of the wilderness: The life of John Muir. New York, NY: Alfred A. Knopf.

Younghusband, F. (1921). The heart of nature. London, UK: John Murray Publisher.

\section{REFERENCES}

Cornell, J. B. (2013). AUM: The melody of love. Nevada City, CA: Crystal Clarity Publishers

Cornell, J. B. (2014). The sky and earth touched me. Nevada City, CA: Crystal Clarity Publishers.

Hanna, W. M. (1954). John of the mountains. Boston, MA: Houghton Mifflin Co.

Khan, H. I. (2005). The music of life: The inner nature and effects of sound. New Lebanon, NY: Omega Publications, Inc.

Singh, K. (2016). The crown of life. The inner sonic key. Ventura, CA: Way to Go Media. Retrieved from https://innersonickey.org/2016/06/21/the-crown-oflife-by-kirpal-singh

Swami Kriyananda (Walters, J. D.). (1996). Rays of the one light: Weekly commentaries on the Bible \& Bhagavad Gita (4th ed.). Nevada City, CA: Hansa Trust, Crystal Clarity Publishers.

Address correspondence to: Joseph Cornell

Sharing Nature Worldwide 14618 Tyler Foote Rd. Nevada City, CA 95959

USA

E-mail: bharat@ananda.org

Received: March 4, 2020 Accepted: March 10, 2020 